\title{
DOES HIGH-SPEED RAIL GENERATE SPILLOVERS ON LOCAL BUDGETS?
}

Aday Hernández

(Universidad de Las Palmas de Gran Canaria)

Juan Luis Jiménez

(Universidad de Las Palmas de Gran Canaria)

\section{CÀTEDRA PASQUAL MARAGALL D'ECONOMIA I TERRITORI}

\section{COL·LECCIÓ DE DOCUMENTS DE TREBALL}

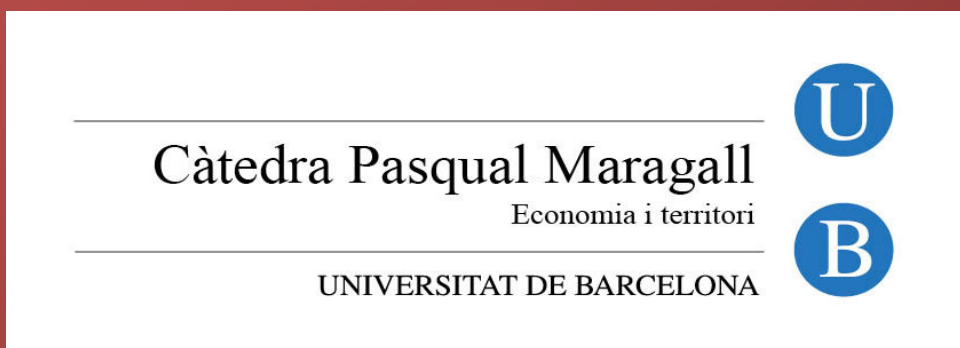

Entitat col-laboradora:

¿ Santander 


\begin{abstract}
Many developed countries have boosted investment into High-Speed Rail (HSR). This infrastructure is costly and requires high investment during the construction and operation periods, which is mainly financed with public funds. This economic effort is seldom set off, which leads to subsidies with the money collected from public debt growth or tax pressure increases. The question that immediately emerges is whether the entrance of this new infrastructure generates spillovers at the local level. In this paper, we answer this question by using local data on economic activity, municipalities' characteristics and local public budgets in Spain for the past decade (2001-2010). To approach to this problem, we use GIS tools and build a database to estimate the impact by considering difference-in-difference analysis. Our estimations yield a general conclusion: when HSR comes to town, both local revenues and the local fiscal gap improve by $10 \%$ and $16 \%$, respectively. These improvements primarily affect municipalities located within $5 \mathrm{~km}$ of an HSR station.
\end{abstract}

Keywords: High Speed Rail; local budgets; difference-in-difference

J.E.L. Classification: H72, L92, L98 


\title{
DOES HIGH-SPEED RAIL GENERATE
}

\section{SPILLOVERS ON LOCAL BUDGETS?}

\author{
Aday Hernández ${ }^{2}$ \\ Juan Luis Jiménez ${ }^{3}$ \\ Departamento de Análisis Económico \\ Departamento de Análisis Económico \\ Aplicado, Universidad de Las Palmas \\ de Gran Canaria \\ Aplicado, Universidad de Las Palmas \\ de Gran Canaria
}

\section{Introduction}

High-speed rail (HSR) has become an alternative to mass transport around the world and countries such as China, Spain, Japan and France have boosted its development. ${ }^{4}$ This type of infrastructure requires high investment costs and high maintenance and operation costs, which are mostly financed with public funds. This investment should be compensated by the positive economic effects (e.g. time savings, reduction of externalities, wider economic effects) that the provision of the infrastructure may generate.

However, this is not always the case. De Rus (2012) shows for the case of Spain and Albalate and Bel (2012) review the main international experiences to highlight the huge costs associated with the infrastructure. Under this scenario, the public funds required for the construction of HSR lines are not going to be recovered, which may lead to public debt growth or tax pressure increases.

Specifically, in Spain, HSR lines are mostly financed by the central government, and cofinanced with European funds, while most of the economic effects occur at the

\footnotetext{
1 Authors thank comments and suggestions by Daniel Albalate, Javier Campos, Beatriz González López-Valcárcel, Jordi Perdiguero, Augusto Voltes-Dorta and an anonymous referee from working paper collection "Cátedra Pasqual Maragall". All errors are ours. Aday Hernández thanks grant by Cátedra Pasqual Maragall (2011).

2 Departamento de Análisis Económico Aplicado. Facultad de Economía, Empresa y Turismo. Universidad de Las Palmas de Gran Canaria. Despacho D. 2-14. Campus de Tafira. 35017. Las Palmas. ahernandez@acciones.ulpgc.es; tel: +34 928458208.

3 Contact author: Departamento de Análisis Económico Aplicado. Facultad de Economía, Empresa y Turismo. Universidad de Las Palmas de Gran Canaria. Despacho D. 2-12. Campus de Tafira. 35017. Las Palmas. juanluis.jimenez@ulpgc.es; tel: +34 928458191.

4 There are planned or existing HSR lines in Africa, Asia, North America, South America and Europe through ambitious network expansion (Campos and de Rus, 2009).
} 
regional or municipality level. Therefore, a controversial relation may arise in the long run between these two government levels. The local government claims to have an infrastructure that it does not finance entirely, wondering about the future positive effects that may not always happen.

Consequently, local governments and mayors attempt to get an HSR station, as if this would spontaneously generate economic benefits for their voters. In particular, during the recent financial crisis, mayors considered that investment in HSR infrastructure may partly solve local problems by improving local economic activity. ${ }^{5}$ However, local governments have to recognise the extra expenses and increases in public services, which may or may not be compensated by the potential economic activity generated by the infrastructure.

The main goal of our paper is to shed light on how the construction of new HSR lines affects local finance considering the main variables of local budgets. Despite the extensive literature regarding the relationship between infrastructure and the impact of public expense (Solé-Ollé, 2006a), previous authors, to our knowledge, have not explored the impact of the infrastructure on local budgets at the municipality level.

In order to analyse this relationship, we build a local database for the past decade (2001-2010) that includes variables that capture not only local economic activity and public budgets, but also the Geographic Information System (GIS) information used to detail potential spillover effects. Our estimations support the fact that HSR improves both local revenues and local budgets after HSR entrance.

Section 2 presents the literature review on HSR effects and local budget analysis. Section 3 provides some facts about HSR projects in Spain, while the database and considered covariates are explained in Section 4. Section 5 develops the empirical strategy and estimations and, lastly, Section 6 summarises the main contributions and results.

\footnotetext{
${ }^{5}$ One recent example is the mayor of Vigo, Abel Caballero, and his defence of the HSR investment for his region. A long version of the interview can be found here: http://www.atlantico.net/noticia/255439/caballero/vigo/recuperacion/economica/
} 


\section{Literature review}

As mentioned above, public investment, particularly transport infrastructure investment, is a powerful mechanism for enhancing economic growth and employment in the short run. Aschauer (1989) was the first to assess the role of public investment in economic growth and productivity improvements. Since then, works have focused on exploring the links between infrastructure investment and macroeconomic variables such as GDP (Munnell, 1990; Holtz-Eakin, 1994; Gramlich, 1994 for a review literature), productivity growth (SACTRA, 1999; Haughwout, 2002) and employment (Vickerman, 2002, Dalemberg et al., 1998).

However, the macroeconomic impacts are useless for making an individual decision about a project because this is context-specific-both in type (line or point infrastructure, etc.) and in its position within the network. Consequently, the spatial dimension needs to be discussed because investment in one region depends on the local conditions, existent transport modes and infrastructure provision in other regions, among others (Vickerman, 1991).

In this setting, we focus on the effect of public infrastructure investment, in particular HSR, assuming that positive effects are translated into effects on the budgets of the administrative entities around the infrastructure. The role of the spatial dimension is widely justified because the infrastructure interacts with the space and the location of the economic activity. ${ }^{6}$ Usually, these effects arise from individual decisions and take place at a disaggregate dimension of the economic activity (Graham, 2006), and that is why we should focus on the municipality level, thereby allowing us to identify variation at a small spatial scale. In this sense, two properties of the analysis are desirable: (i) avoiding predefined units such as administrative areas (Spanish municipalities in our case) and (ii) emphasising distance or density in order to include a transport dimension that determines the

\footnotetext{
${ }^{6}$ The mechanisms that produce changes in the spatial dimension of the economic activity such as agglomeration economics arise from technological spillovers, consumer concentration or improvements in the labour market (see Rosenthal and Strange, 1995 for a further explanation).
} 
spatial behaviour of the impacts. These two conditions are further analysed in Section 3.

From the previous discussion, it is clear that public transport investment affects the revenues of administrative entities if the potential positive benefits of the investment capitalises in the region generating additional economic activity. However, the final effect is likely to depend on how the increased spending is financed. Empirical studies, at the aggregate level, such as those of Engen and Skinner (1996) find evidence that increases in tax rates reduce the rate of economic growth. An increase in public capital, which, in most cases, requires an increase in tax rates, will stimulate economic growth only if the productivity impact of the public capital exceeds the adverse tax impact.

Consequently, the financing mechanism and tax structure need to be considered. Transport policy in Spain is in the hands of national and regional governments, and the fiscal policy provides too few incentives for an efficient use of funds. There is no direct correspondence between expenses and collected taxes, encouraging regions to exaggerate their needs for funds. Therefore, there is no direct relation between the entity that finances the infrastructure (national/supranational) and the entity that gets benefits (regional/local) from economic activity increases.

Further, HSR is associated with a "tunnel effect" (Gutiérrez Puebla, 2004). HSR develops the final nodes, lacking the generation of economic activity throughout the territory where it develops. Hence, a polarisation effect leads to increased accessibility at the nodes of the infrastructure, isolating intermediate regions from the poles (which attract business). This allows us to focus only on the effects that take place surrounding the station (at different distances).

The analysis of distances is an important consideration to appraise the construction of a new infrastructure. A relevant question is whether the infrastructure performs better in the region where it is built or plays in favour of adjacent regions. On one hand, the infrastructure may encourage new activities and the location of new enterprises, while, on the other hand, dispersion forces may lead to a delocalisation of firms, reducing the expected benefits of the infrastructure (Krugman and Venables, 1995; Puga, 2002). The final result 
depends on the local conditions, existent transport modes and infrastructure provision in other regions.

Regarding to regional and sectorial impacts, we must consider, as Esteban Martín (1998) claims, that cities served by HSR usually have alternative transport mode, such as conventional train or. These are clearly affected by the new alternative and operator companies do reduce the number of services. Moreover, there may be some second-order effects on directly linked sectors such as tourism or hospitality. Business tourism and conferences benefit from new HSR services, but it may produce a reduction in the number of overnight stays, cutting tourist expenditure and the consumption of hotel services.

Albalate and Bel (2012) review the experiences of HSR around the world and literature related to regional effects, reporting that regions whose economic conditions compare unfavourably with those of their neighbours, a new HSR infrastructure may even result an overall negative impact (Givoni 2006; Van den Berg and Pol 1998; Thompson 1995).

For this reason, we consider in our analysis variables that capture the local environment. Thus, we focus on the academic literature on local fiscal budgets and the related literature on Spanish municipalities. Zafra-Gómez et al. (2009) focus on identifying the key determinants of local financial performance: income, unemployment and population, among others. Other references are linked to the identification of the determinants of local deficits or tax burdens, as in Lago-Peñas (2004) for the region of Galicia and Sollé-Ollé (2006a), Fluvià et al. (2008), Bastida et al. (2009) and Benito et al. (2010) for Spanish-wide samples.

All these studies consider population to be the main variable. This covariate allows us to test for scale economies in the provision of public services at a local level (see Allers et al., 2001; Petterson-Lidbom, 2001; Castells et al., 2004; Fluvià et al., 2008, among others). Other important variables are the proportion of elderly $(>65)$ and young $(<20)$ residents and the immigration rate (e.g. Zafra-Gómez et al., 2009; Voltes-Dorta et al., forthcoming). These age groups are key drivers of demand for municipal services, such as employment, health and education, while a significant 
proportion of senior citizens may lead to a decrease in demand for other services such as sports facilities (Zárate and Vallés, 2012).

Lastly, income per capita and the unemployment rate are economic indicators that also affect local budgets (Bastida et al., 2009; Benito et al., 2010). The effect of tourism on local budgets must also be taken into account because of the several positive and negative effects that it may induce (see Voltes-Dorta et al., forthcoming). This paper is based on previous contributions, but it differentiates from those in several ways: firstly, it uses GIS analysis to capture the spatial component, which is crucial for assigning economic impacts, and secondly, it considers a difference-in-difference (DiD) methodology.

\section{HSR in Spain $(A V E)$ : some facts}

Transport infrastructures play a key role in European Union policy, and total investment during the 2000-2006 period was 859€ billion. The cost of establishing an efficient trans-European transport network (TEN-T) has been estimated to be over $1.5 €$ trillion for the $2010-2030$ period.

Spain has also followed the European strategy and has bet intensively on transport infrastructure. The Spanish government has promoted heavily the development of an HSR network as shown in the Strategic Infrastructure and Transport Plan, which includes the main activities in infrastructure and transport between 2005 and 2020, with a total investment of $241,392 €$ million. It values significantly the possibilities that infrastructures have for regional cohesion and employment, as proven by its commitment to create an HSR network that aims to have $90 \%$ of the mainland Spanish population located within $50 \mathrm{~km}$ of a station. At the end of the period, the whole network will have $10,000 \mathrm{~km}$ of HSR.

The 3,000 km of HSR in service (at December 2013) is the longest high-speed network in Europe and second worldwide and it is composed of four main corridors. Table 1 shows the lines in service with all the cities through which the 
network develops and the first year of operation and Figure 1 describes the geographical distribution of the HSR network.

Table 1. HSR network (AVE) in Spain in 2013

\begin{tabular}{|c|c|c|}
\hline Lines in services & Cities & $\begin{array}{c}\text { First year of } \\
\text { operation }\end{array}$ \\
\hline Madrid - Seville & $\begin{array}{c}\text { Madrid - Ciudad Real - Puertollano - } \\
\text { Córdoba - Seville }\end{array}$ & 1992 \\
\hline $\begin{array}{c}\text { Madrid - Zaragoza - } \\
\text { Barcelona }\end{array}$ & $\begin{array}{c}\text { Madrid - Guadalajara - Catalayud - } \\
\text { Zaragoza - Lleida } \\
\text { Lleida - Campo de Tarragona } \\
\text { Campo de Tarragona - Barcelona- } \\
\text { Sants }\end{array}$ & $\begin{array}{l}2006 \\
2008\end{array}$ \\
\hline Madrid - Toledo & Madrid - Toledo & 2005 \\
\hline Zaragoza - Huesca & Zaragoza - Tardienta - Huesca & 2005 \\
\hline Madrid - Segovia - Valladolid & Madrid - Segovia - Valladolid & 2007 \\
\hline Córdoba - Málaga & $\begin{array}{c}\text { Madrid - Córdoba - Puente Genil - } \\
\text { Antequera - Málaga }\end{array}$ & 2007 \\
\hline Perpiñan - Figueres & Figueres - France & 2009 \\
\hline Madrid - Valencia & $\begin{array}{c}\text { Madrid - Cuenca - Requena-Utiel - } \\
\text { Valencia }\end{array}$ & 2010 \\
\hline Madrid - Alicante & $\begin{array}{l}\text { Cuenca - Albacete } \\
\text { Albacete - Alicante }\end{array}$ & $\begin{array}{l}2010 \\
2013\end{array}$ \\
\hline Olmedo - Zamora - Galicia & $\begin{array}{c}\text { Orense - Santiago de Compostela - A } \\
\text { Coruña }\end{array}$ & 2011 \\
\hline Barcelona - French Border & $\begin{array}{c}\text { Barcelona-Sants - Barcelona-Sagrera } \\
\text { - Girona - Figueres }\end{array}$ & 2013 \\
\hline
\end{tabular}

Source: Own elaboration. 
Figure 1. HSR network (AVE) in Spain in 2013

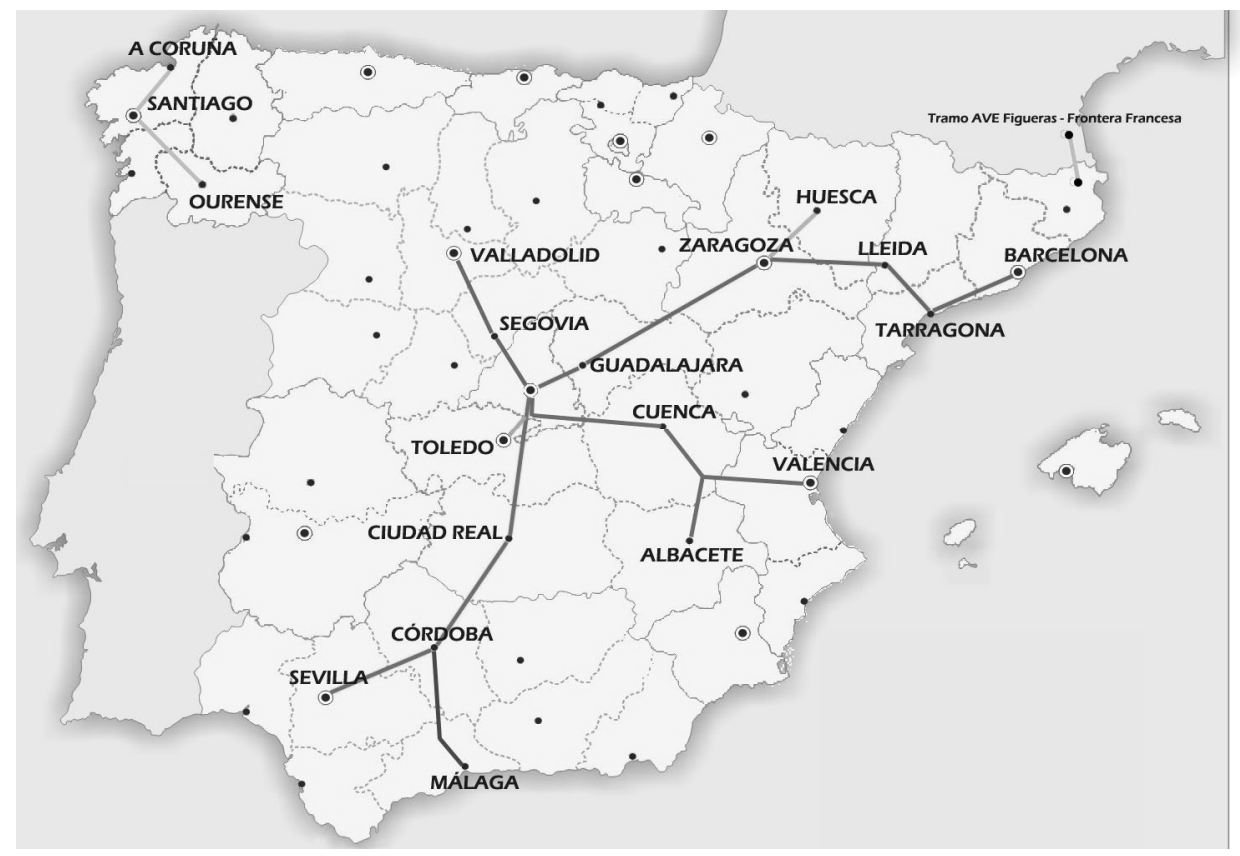

Source: ADIF.

The establishment of the HSR has reorganised the transport markets in Spain. In fact, Jiménez and Betancor (2012) study the strategic reactions of airlines in the Spanish transport market after the entrance of HSR. By using panel data from 1999 to 2009 and applying an instrumental variable analysis, Jiménez and Betancor (2012) conclude that "(...) the entry of HSR in Spain has reduced on average the number of air transport operations by 17 percent, though this result differs, depending on the route and the airlines considered".

Moreover, two more facts have occurred. First, the entrance of HSR has allowed demand to increase by between $8 \%$ and $35 \%$, depending on the routes, without differentiating between deviated and generated demand (see Annex 1 for a further analysis of the routes). Consequently, the entrance of HSR has changed the market share of air transport. 


\section{Database}

To compute the impact of HSR entrance on our variables of interest, we use a panel dataset composed of 3,400 Spanish municipalities with more than 1,000 inhabitants in the period 2001-2010. Our main source is the La Caixa's Economic Yearbook, which includes a set of the variables of interest regarding population, extension and the importance of tourism, among others. A second source is provided by the Ministry of Public Administration, which collects variables regarding the financial situations of municipalities (revenues, expenses, public debt or deficit, among others). ${ }^{7}$

The HSR network develops along the territory and has economic effects on the surrounding populations. The spatial dimension of its effects requires the use of GIS $^{8}$ to reference the database geographically and to capture the role of the distance. The procedure is as follows:

1. Localise HSR stations geographically. Spain has four main corridors but we only include HSR lines that started before 2009 (see Table 1). Ideally, we would appraise the existent HSR network but the lack of a reliable database prevents this.

2. To capture the spatial dimension, we establish concentric circles around HSR stations. When these circles cover only part of the surface of the municipality, we only consider the proportion of the municipality affected by the infrastructure. The aim is to establish influence areas to examine the impact of the relevant variables on local budgets. We repeat this procedure for concentric circles of 5, 10 and $20 \mathrm{~km} .^{9}$

The point of building concentric circles of different kilometres around the HSR station is twofold; to limit the influence area of the infrastructure and to explore how the impact of the infrastructure evolves over distance. To capture the impact, we need to georeference the previous database with a set of variables of interest, such as:

\footnotetext{
${ }^{7}$ Data were collected from http://serviciosweb.meh.es/apps/entidadeslocales/.

${ }^{8} \mathrm{GIS}$ is a system of hardware and software used for the storage, retrieval, mapping and analysis of geographic data. A GIS can be thought of as a system-it digitally creates and "manipulates" spatial areas.

${ }^{9}$ See Hernández (2012) for a more detailed description of this procedure.
} 
i) Financial autonomy per capita it: the proportion of local revenues included in chapters I, II and III relative to total local revenues regarding population per municipality $i$ in year $t$. This proxies for the municipality's ability to generate revenue as opposed to being dependent on central or regional government transfers. Source: own elaboration from the database of the Ministry of Public Administration.

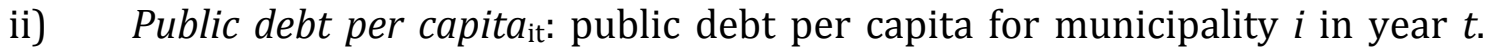
Source: Ministry of Public Administration.

iii) Fiscal gap per capita ${ }_{i t}$ : difference between expenditure per capita (net of public debt) and revenue per capita (net of current and capital transfers). This alternative measure of deficit focuses on expenditure linked to the provision of public services and revenue raised within the municipality (Grembi et al., 2012; Voltes-Dorta et al., forthcoming). This covariate is better than local fiscal deficit because it does not consider the potential effect of financial transfers from regional or central government due to HSR entrance. Therefore, it is a better proxy to the local economic approach.

iv) Yearly property taxit: tax assessed on real estate by the local government. The tax is usually based on the value of the property (including the land) owned. Source: Ministry of Public Administration.

v) Touristic index $i$ : this variable captures whether municipality $i$ is a touristic one. As carried out by Voltes-Dorta et al. (forthcoming), this covariate was constructed as a revenue-based location quotient of municipal tourism intensity. Based on data from La Caixa's Economic Yearbook, it is the ratio between the municipality's percentage contribution to the tourism subsection of the national trade tax revenues and the national percentage contribution to the tourism subsection of the national trade tax revenues. Source: own elaboration from La Caixa.

vi) Stratified population $i$ : this covariate determines the stratus of the population which corresponds to municipality $i$ in year $t$. According to the Regulatory Law of Local Municipalities (Ley Reguladora de las Bases de Régimen Local), municipalities must offer a range of compulsory services according to population criteria. This law clearly conditions the local expenses, and thus we decided to include the stratified population as an exogenous variable. ${ }^{10}$ Source: own elaboration from La Caixa's Economic Yearbook.

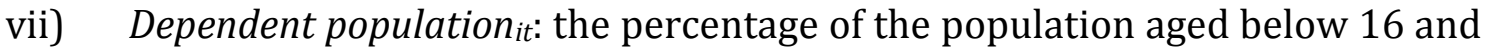
above 65 in municipality $i$ in year $t$. This type of variable is widely used in local analysis as explained in section 2 (see Solé-Ollé, 2006a; Gonçalvez and Veiga, 2007; Benito et al.; 2009). Source: National Institute of Statistics and own elaboration.

\footnotetext{
10 In particular, the strata are between 0 and 5,000 inhabitants; 5,000 to 20,$000 ; 20,000$ to 50,000 ; larger than 50,000 ; capitals of provinces (NUTS 3 regions); and municipalities larger than 250,000 inhabitants.
} 
viii) Area: measures the surface area of municipality $i$ in square kilometres. This figure is obtained from the National Institute of Statistics.

ix) Population densityit: the ratio between the population and the extension of municipality $i$ in year $t$. Source: National Institute of Statistics and own elaboration.

$\mathrm{x}$ Unemployment $t_{i t}$ : the unemployment rate in municipality $i$ in year $t$ that is published in the Economic Yearbook of La Caixa.

xi) We consider another variable called Crisis $t_{t}$ that is a binary variable that takes 1 from 2008 to 2010, and 0 otherwise. This explanatory variable controls for the potential effect of the economic crisis and its adverse effect on local finances.

xii) Finally, we include a Trend variable that ranges from 1 to 10 to control for the potential time effects for all municipalities.

Table 2 shows the descriptive statistics of the variables considered.

Table 2. Descriptive statistics. All database. 2001-2010

\begin{tabular}{ccccc}
\hline Variable & Average & $\begin{array}{c}\text { Standard } \\
\text { deviation }\end{array}$ & Minimum & Maximum \\
\hline Revenues per capita & 433.74 & 406.08 & 0 & $21,756.04$ \\
Fiscal gap per capita & 349.46 & 409.89 & $-23,783.16$ & $5,397.35$ \\
Yearly property tax & 0.565 & 0.150 & 0 & 1.3 \\
Debt per capita & 43.36 & 92.57 & -1.53 & $5,054.02$ \\
Touristic index & 0.74 & 2.33 & 0 & 29.09 \\
Population (stratified) & 1.53 & 0.81 & 1 & 5 \\
Dependent population & 0.35 & 0.05 & 0.18 & 0.62 \\
Unemployment & 7.7 & 4.29 & 0 & 30.5 \\
Density of population & 369.12 & $1,261.34$ & 1.56 & 22,401 \\
Crisis & 0.30 & & 0 & 1 \\
\hline
\end{tabular}

Source: Own elaboration. 
Revenues per capita show average revenue of 433.74 euros, while the fiscal gap and debt per capita are 349.46 and 43.36, respectively. The latter show one of the main problems in Spain: the persistent debt of local governments. On average, the density population is equal to 369.12 people and unemployment with respect to the total population is 7.7. With regard to the touristic index, the average value is 0.74, which varies between 0 for non-touristic municipalities and 29.09 for the most touristic one.

However, our question of interest is whether the entrance of HSR in Spain modifies the local budgets of municipalities when it arrives. Our interest is in comparing changes in the main variables after the entrance of HSR in these municipalities. For this reason, Table 3 includes average data for budget covariates and the yearly property tax in order to analyse in a descriptive way whether this exogenous change (the entrance of HSR) has modified them.

To do this, we consider two questions: firstly, we compare municipalities within an influence area of HSR of $5 \mathrm{~km}$ with those that are out of this influence area; secondly, we compare the situation before and after the entrance of HSR. Moreover, a t-test for the before and after data was carried out.

Table 3. Average data by year of entrance. Before and after analysis

\begin{tabular}{ccccc}
\hline \multirow{2}{*}{ Variable } & \multicolumn{2}{c}{ Cities with HSR [0-5 kms) } & \multicolumn{2}{c}{ Cities without HSR } \\
\cline { 2 - 4 } & Before & After & Before & After \\
\hline If HSR entrance was in 2003 & & & \\
\hline Revenues per capita & 366.54 & $544.90^{*}$ & 336.41 & $439.57^{*}$ \\
Fiscal gap & 175.70 & $240.86^{*}$ & 266.84 & $384.71^{*}$ \\
Yearly property tax & 0.59 & 0.60 & 0.58 & $0.61^{*}$ \\
Debt per capita & 43.06 & 47.47 & 38.01 & $43.81^{*}$ \\
\hline If HSR entrance was in 2005 & & & & $457.79^{*}$ \\
\hline Revenues per capita & 344.58 & $491.47^{*}$ & 342.23 & $426.74^{*}$ \\
Fiscal gap & 213.97 & $290.28^{*}$ & 280.84 & $0.62^{*}$ \\
Yearly property tax & 0.64 & 0.64 & 0.59 & $45.67^{*}$ \\
Debt per capita & 44.36 & 49.94 & 37.62 & \\
\hline
\end{tabular}




\begin{tabular}{ccccc}
\hline If HSR entrance was in $\mathbf{2 0 0 6}$ & & & & \\
\hline Revenues per capita & 401.22 & $552.01^{*}$ & 359.88 & $472.78^{*}$ \\
Fiscal gap & 194.97 & $314.15^{*}$ & 281.10 & $460.90^{*}$ \\
Yearly property tax & 0.66 & 0.66 & 0.60 & $0.62^{*}$ \\
Debt per capita & 42.49 & $56.18^{*}$ & 38.17 & $47.95^{*}$ \\
\hline If HSR entrance was in 2007 & & & \\
\hline Revenues per capita & 452.39 & 474.38 & 374.55 & $468.07^{*}$ \\
Fiscal gap & 166.03 & $364.07^{*}$ & 289.78 & $506.55^{*}$ \\
Yearly property tax & 0.60 & 0.59 & 0.60 & $0.62^{*}$ \\
Debt per capita & 38.42 & $46.51^{*}$ & 38.68 & $48.87^{*}$ \\
\hline If HSR entrance was in 2008 & & & & \\
\hline Revenues per capita & 399.43 & $516.16^{*}$ & 390.77 & $474.57^{*}$ \\
Fiscal gap & 208.54 & $368.70^{*}$ & 312.18 & $529.35^{*}$ \\
Yearly property tax & 0.65 & 0.64 & 0.61 & $0.62^{*}$ \\
Debt per capita & 51.01 & $65.51^{*}$ & 39.59 & $54.06^{*}$ \\
\hline
\end{tabular}

Source: Own elaboration. $\left(^{*}\right)$ Asterisk indicates a statistically significant (5\%) difference between the before and after data by the group of cities (treatment and control group).

Generally, we observe that the mean tests are statistically significant for all variables considering cities without HSR and for revenues per capita and fiscal gap for cities with HSR. Independent of the year of entrance, the average of our relevant variables is higher for cities with HSR than without HSR and for the scenario after entrance compared with before.

By focusing on cities with HSR, we find that the yearly property tax does not vary, which implies a pressure on real estate to keep constant before and after the entrance of HSR. This is not the case for cities without HSR, where the yearly property tax has been used as a tool to modify municipal budgets. Lastly, we observe that the mean test of debt per capita is statistically significant when we consider a year of entrance after 2006. This finding implies that there is a tendency of municipalities to borrow external financial funds. 


\section{Estimations}

Despite previous descriptive results, a causal relationship must be found in order to draw structural conclusions. As detailed in previous sections, our main aim is to evaluate whether HSR entrance improves local budgets in the municipalities where it is located. For this reason, we firstly estimate whether this exogenous factor increases local revenues (as a proxy of higher economic activity). The increase in economic activity directly translates into higher fiscal revenues through the collection of taxes such as business tax, property tax, waste taxes, taxes on vehicles and taxes on construction, among others.

Moreover, if local revenues increase owing to more economic activity (we also analyse evolution of local tax increase in Annex II), this may also generate higher expenses because new services may be provided. To test this fact, we estimate the impact of HSR entrance on the fiscal gap and debt per capita. When these new services are funded by own local revenues, the fiscal gap may be worse off; otherwise, it may increase debt per capita.

For this reason, we consider a Difference-in-difference (DiD hereafter) approach to estimate the impact of our variable of interest (the entrance of HSR) on the endogenous variables. DiD is an econometrics technique that captures the effect of a treatment in a given period. The DiD estimation represents the difference between the pre-post, within-subject differences of the treatment and control groups. Our treatment group is the set of municipalities affected by the introduction of the new transport infrastructure and the control group is the municipalities that are not affected. ${ }^{11}$

As the benchmark, we estimate equation [1].

\footnotetext{
11 The Difference-in-difference estimator is the difference in the average outcome in the treatment group before and after the change, unless the difference in the average score in the control group before and after the change. So, to control this precise effect we have to include three binary variables in our estimations: one which control for potential differences in treatment group (CitywithHSR in our analysis); one more that control for potential changes before and after the event (PeriodafterHSR in equation 1); and finally, the interaction of those previous variables, i.e., the DiD estimator.
} 
$Y_{i t}=\beta_{0}+\beta_{1}$ CitywithHSR $+\beta_{2}$ PeriodafterHSR $+\beta_{3}$ DiD +

$+\beta_{4}$ Touristicindex ${ }_{i}+\beta_{5}$ Population (stratified $)_{i t}+$

$+\beta_{6} \%$ DependentPop $_{i t}+\beta_{7}$ Unemployment $_{i t}+\beta_{8}$ PopDensity $_{i t}+$

$+\beta_{9}$ Area $_{i}+\beta_{10}$ Crisis $_{t}+\beta_{11}$ Trend $+\varepsilon_{i t}$

In particular, our dependent variables $\left(Y_{i t}\right)$ are those related to local municipalities that we consider to be relevant and affected by the new infrastructure such as local revenues per capita, the yearly property tax (IBI in Spanish), fiscal gap per capita and debt per capita. We estimate these individually and separately according to [1], but we have to interpret them somehow jointly because a joint interpretation allows us to understand the final effect of the infrastructure on local budgets.

However, one of the most basic assumptions of differences-in-differences models is that the temporal effect in the two groups of municipalities is the same in the absence of entrance of HSR. So, we first have to test whether both treatment and control group show same trend before the opening of the new station. This has been called the 'identifying assumption'. In order to check it, we estimate a similar equation than [1] for each endogenous variable and for each route but we substitute DiD estimator by separate dummies for treatment and control municipalities, in order to check whether the time trends in the pretreatment period were the same. ${ }^{12}$

The econometric result indicates that we cannot reject even at least at 10 percent that affected and control groups (cities with and without HSR) behave equally before the introduction of the HSR. This fact does not occur in all routes-years (see Tables 4 to 7 and following explanations).

Table 4 only shows the DiD estimation of revenues per capita on the entrance of HSR considering that these vary depending on the municipality and distance to the infrastructure. ${ }^{13}$ In this table, each cell provides the DiD estimator under different

\footnotetext{
12 The empirical strategy is the following one: firstly we create time-dummies for both control and treatment group. Then, we estimate each equation replacing D-i-D variables for these previous variables generated. Finally, we test whether coefficientes for each group of time-dummies are equal or not (see Albalate, 2008, for further explanation of this empirical strategy).

${ }^{13}$ All estimations in Tables 4 to 7 consider all the covariates explained in equation [1]. They were estimated by solving potential heteroskedastic problems. $R^{2}$ for all estimations ranges from 0.13 to 0.27 . Results for covariates were those expected at academic literature, i.e., higher tourism activity, higher revenues (Voltes-Dorta et al, 2013);
} 
conditions; thus, the row represents the year of entrance of the transport infrastructure and the column represents the spatial dimension depending on whether the municipality has an HSR station or is within a certain distance (we consider 0-5 km, 5-10 km and 10-20 km).

Table 4. DiD estimation of revenues per capita on the entrance of HSR

\begin{tabular}{|c|c|c|c|c|c|}
\hline $\begin{array}{c}\text { Entrance of } \\
\text { HSR in... }\end{array}$ & Observations & HSR station & $\begin{array}{c}\text { HSR station + } \\
\text { buffer } 5 \mathrm{kms}\end{array}$ & $\begin{array}{c}{[5-10} \\
\text { kilometers] }\end{array}$ & $\begin{array}{c}{[10-20} \\
\text { kilometers] }\end{array}$ \\
\hline 2003 & 28,707 & 39.56 (20.98)* & $\begin{array}{c}70.36 \\
(32.45)^{* *}\end{array}$ & $\begin{array}{c}301.59 \\
(80.26)^{* * *}\end{array}$ & 30.43 (31.18) \\
\hline 2005 & 28,236 & $\begin{array}{c}60.17 \\
(22.29)^{* * *}\end{array}$ & $34.78(21.35)^{*}$ & $74.20(31.50)^{* *}$ & 6.34 (16.89) \\
\hline 2006 & 28,174 & $\begin{array}{c}83.32 \\
(26.91)^{* * *}\end{array}$ & $47.21(26.41)^{*}$ & $11.47(78.72)$ & $17.11(25.19)$ \\
\hline 2007 & 28,760 & $\begin{array}{c}38.87 \\
(24.70)\left(!^{*}\right)\end{array}$ & 47.15 (25.17)* & $-18.23(44.78)$ & $-19.41(13.13)$ \\
\hline 2008 & 28,425 & $\begin{array}{c}69.11 \\
(33.21)^{* *}\end{array}$ & $\begin{array}{c}52.33 \\
(23.65)^{* *}\end{array}$ & $-11.36(26.80)$ & $-0.28(16.32)$ \\
\hline
\end{tabular}

Note $1:{ }^{* *} 1 \%, * * 5 \%, * 10 \%$ significance test. Standard deviation in brackets.

Note 2: Identifying assumption is satisfied in bolded rows.

The DiD estimator of local revenues per capita yield a general conclusion: the entrance of HSR in Spanish municipalities has induced an increase in own revenues collected by local governments. Moreover, this positive spillover goes from municipalities with HSR stations up to a radius of $5 \mathrm{~km}$. In the two oldest routes, this effect increases to a $10 \mathrm{~km}$ radius. However, only data from 2005 satisfy the identifying assumption.

By using the average revenues per capita in Table 3 and the coefficients estimated in Table 4, we find that HSR entrance would induce an increase in local revenues per capita close to $10 \%$.

This effect may have been induced by the greatest economic development at the local level. Hernández (2012) estimates the impact of the HSR network on employment, which shows a direct relation between the infrastructure and generation of economic spillovers. However, do they really improve the

economies of scale (population) in fiscal gap per capita; lower outcomes at crisis time; etc. All estimation results are available upon request. 
performance of local finances? Table 5 repeats the previous procedure by focusing on the fiscal gap per capita.

Table 5. DiD estimation of the fiscal gap per capita on the entrance of HSR

\begin{tabular}{|c|c|c|c|c|c|}
\hline $\begin{array}{c}\text { Entrance of } \\
\text { HSR in... }\end{array}$ & Observations & HSR station & $\begin{array}{l}\text { HSR station + } \\
\text { buffer } 5 \text { kms }\end{array}$ & $\begin{array}{c}{[5-10} \\
\text { kilometers] }\end{array}$ & $\begin{array}{c}{[10-20} \\
\text { kilometers] }\end{array}$ \\
\hline 2003 & 25,807 & $-23.98(27.71)$ & $-53.49(31.07)^{*}$ & $\begin{array}{l}-158.87 \\
(98.10)\end{array}$ & $-65.78(37.84)^{*}$ \\
\hline 2005 & 25,384 & $\begin{array}{c}-52.06 \\
(32.35)^{*}\end{array}$ & $\begin{array}{c}-67.88 \\
(19.41)^{* * *}\end{array}$ & $-14.21(28.34)$ & $-27.16(16.43)$ \\
\hline 2006 & 25,328 & $\begin{array}{c}-75.45 \\
(44.45)^{*}\end{array}$ & $\begin{array}{c}-56.37 \\
(23.98)^{* *}\end{array}$ & $45.89(48.47)$ & $-19.79(24.73)$ \\
\hline 2007 & 25,855 & $\begin{array}{c}-60.19 \\
(28.77)^{* *}\end{array}$ & $-16.96(32.03)$ & $44.18(40.36)$ & $-3.18(19.76)$ \\
\hline 2008 & 25,554 & $-113.33(80.44)$ & $\begin{array}{c}-60.68 \\
(28.64)^{* *}\end{array}$ & $-20,85(27.46)$ & 10.68 (19.67) \\
\hline
\end{tabular}

Note $1: * * * 1 \%, * * 5 \%, * 10 \%$ significance test. Standard deviation in brackets.

Note 2: Identifying assumption is satisfied in bolded rows.

Estimations for 2006 and 2008 may be biased because they do not satisfy the identifying assumption using test described by Albalate (2008). Nevertheless, the statistical significance of the variable and negative sign of DiD suggest that local revenues increase after HSR entrance and that local governments take advantage of this better performance in order to improve their own local fiscal gap. As in Table 4, the most significant coefficients are those for municipalities located within a $5 \mathrm{~km}$ radius and those where HSR entrance occurred in the early years.

By comparing these positive effects on the fiscal gap per capita with the average data before entrance described in Table 3, the estimated effect on the fiscal gap is close to $-16 \%$, namely there is a higher surplus (or lower deficit) due to HSR entrance.

The estimations in Table 6 use debt per capita as an endogenous variable. No coefficients, except in two cases, show statistical significance, implying no change in local debt per capita after HSR entrance in affected municipalities. 
Table 6. DiD estimation of public debt per capita on the entrance of HSR

\begin{tabular}{cccccc}
\hline $\begin{array}{c}\text { Entrance of } \\
\text { HSR in... }\end{array}$ & Observations & HSR station & $\begin{array}{c}\text { HSR station + } \\
\text { buffer 5 kms }\end{array}$ & $\begin{array}{c}{[\mathbf{5 - 1 0}} \\
\text { kilometers] }\end{array}$ & $\begin{array}{c}{[\mathbf{1 0 - 2 0}} \\
\text { kilometers] }\end{array}$ \\
\hline $\mathbf{2 0 0 3}$ & 25,807 & $2.62(15.55)$ & $-0.80(5.53)$ & $4.95(3.90)$ & $-0.88(9.23)$ \\
$\mathbf{2 0 0 5}$ & 25,384 & $-7.09(15.58)$ & $2.37(6.04)$ & $1.19(5.31)$ & $-2.80(3.67)$ \\
$\mathbf{2 0 0 6}$ & 25,328 & $26.23(23.86)$ & $11.44(7.64)$ & $2.45(6.72)$ & $-4.99(4.59)$ \\
$\mathbf{2 0 0 7}$ & 25,855 & $14.82(15.79)$ & $5.09(6.24)$ & $\mathbf{- 9 . 5 1 ( 4 . 2 9 ) * *}$ & $-\mathbf{- 7 . 9 4 ( 3 . 0 6 ) * *}$ \\
$\mathbf{2 0 0 8}$ & 25,554 & $54.95(57.54)$ & $12.96(13.54)$ & $0.35(5.14)$ & $-3.23(4.07)$ \\
\hline
\end{tabular}

Note $1:{ }^{* * *} 1 \%,{ }^{* *} 5 \%,{ }^{*} 10 \%$ significance test. Standard deviation in brackets.

Note 2: Identifying assumption is satisfied in bolded rows.

To summarise these results, we must highlight the capacity of HSR infrastructure to generate spillovers at the local level. The increase of revenues at the municipality level may generate two types of spillovers, as explored by Solé-Ollé (2006b): benefit spillovers that arise from the provision of local public goods and crowding spillovers that arise from the crowding of facilities by residents in neighbouring jurisdictions. Therefore, from the direct effects, other benefits may arise from the provision of public infrastructure. All of these are associated with the increase in density and the concentration of jobs, facilities and economic agents. In this sense, Hernández (2012) supports this idea by capturing a positive and significant effect of HSR infrastructure on employment density at the local level in Spain.

Lastly, another important aspect is how regions may compete to attract economic activity through a reduction in the tax rate or increases in public facilities (Dembour and Wauthy, 2009). Our analysis suggests no competition in property taxes, as Delgado and Mayor (2011) find for nominal rates on data on 2004, and no increases in public expenditure beyond the optimal one; moreover, there is a reduction in the fiscal gap when comparing cities with and without HSR infrastructure. 


\section{Conclusions}

HSR infrastructure is often subsidised with public money collected from public debt growth or tax pressure increases. These costly infrastructures generate social benefits that should set off the huge costs of investment, maintenance and operation. Social benefits are mainly time savings and the reduction in operating costs; however, we are interested in analysing the impact of the infrastructure on local budgets.

The question that we answer in this paper is whether the entrance of this new infrastructure generates spillovers at the local level. The argument behind our analysis is that the generation of new economic activity influences local budgets by increasing public revenues. However, the new infrastructure may induce extra expenses because the need to provide new services or facilities may affect the local fiscal gap, namely the difference between own local expenditure and local revenue (excluding transfers).

This paper has two main novelties because we consider the use of GIS tools to capture the role of distance and to assess whether we can determine the influence area of the infrastructure and we explore the impact of infrastructure at the local level. To our knowledge, no previous paper has focused on these impacts.

We consider a local database in Spain for the last decade (2001-2010) to appraise these questions individually. Our DiD estimations show that there is an improvement in the public revenues and the fiscal gap, which means that there is an increase in economic activity and thereby extra revenues. These extra revenues are generated by an increase in economic activity and not due to an increase in tax rates. Moreover, this effect is most noticeable in those municipalities located within a $5 \mathrm{~km}$ radius of an HSR station.

Further research is required in this field. It would be interesting to examine the mechanisms of these spillovers to understand the roles of the input and product markets. This would be essential from a policy perspective to determine the optimal location of an HSR station. More research is also required to explore the role of the institutional framework in the impact of the infrastructure on the spillover effects. 


\section{References}

Albalate, D. 2008. Lowering blood alcohol content levels to save lives: The European experience. Journal of Policy Analysis and Management, 27(1), 20-39.

Albalate, D., and Bel, G., 2012. High-Speed Rail: Lessons for Policy Makers from Experiences Abroad. Public Administration Review, 72 (3), 336-349, May/June 2012.

Allers, M., de Haan, J., and Sterks, C., 2001. Partisan influence on the local tax burden in the Netherlands. Public Choice 106, 351-363.

Aschauer, D, A., 1989. Is public expenditure productive? Journal of Monetary Economics, 23, 177-200.

Bastida, F., Benito, B., and Guillamón, M., 2009. An empirical assessment of the municipal financial situation in Spain. International Public Management Journal 12 (4), 484-499.

Benito, B., Bastida, F., and Muñoz, M., 2010. Factores explicativos de la presión fiscal municipal. Spanish Accounting Review 13 (2), 239-283.

Campos, J., and de Rus, G., 2009. Some stylized facts about high-speed rail: A review of HSR experiences around the world. Transport Policy, 16 (1), pp. 19-28.

Delgado, F. J., Mayor, M. 2011. Tax mimicking among local governments: some evidence from Spanish municipalities. Portuguese Economic Journal, 10, 149-164.

Dembour, C., and Wauthy, X., 2009. Investment in public infrastructure with spillovers and tax competition between contiguous regions. Regional Science and Urban Economics, 39, 6, 679-687.

de Rus, G., 2012. Economic evaluation of the high speed rail. Expert Group on Environmental Studies, Ministry of Finance, Sweden, 2012. Available at http://www.ems.expertgrupp-se/Default.aspx?pageID=3. 
Engen, J. S., and Skinner, 1996. Taxation and Economic Growth, National Tax Journal, 1996:617-642.

Esteban Martín, V., 1998. La Alta Velocidad Ferroviaria en la Unión Europea. Su Impacto Urbano en Francia y España [High-speed Rail in the European Union: Urban Impact in France and Spain]. Geographicalia 36: 19-32.

Givoni, Moshe. 2006. Development and Impact of the Modern High-Speed Train: A Review. Transport Reviews 26(5): 593-611.

Gonçalvez, L., and Veiga, F., 2007. Polítical business cycles at the municipal level. Public choice 131 (1), 45-64.

Graham, D, J., 2006. Investigating the link between productivity and agglomeration for UK industries. Report prepared for UK Department for Transport.

Gramlich, E, M., 1994. Infrastructure investment: A review essay. Journal of Economic Literature, 32, 1176-1196.

Grembi, V., Nannicini, T., Troiano, U. 2012. Policy Responses to Fiscal Restraints: A Difference-in-Discontinuities Design. Harvard University Working Paper.

Gutiérrez Puebla, J., 2004. El tren de alta velocidad y sus efectos espaciales. Investigaciones Regionales, 5, 199-221.

Haughwout, A. F., 2002. Public infrastructure investments, productivity and welfare in fixed geographic areas. Journal of Public Economics, 83(3), March 2002, 405-428.

Hernández, A., 2012. Los efectos territoriales de las infraestructuras: La inversión en redes de Alta Velocidad Ferroviaria. FEDEA, Colección Estudios Económicos 0511.

Holtz-Eakin, D., 1994. Public-sector capital and the productivity puzzle. Review of Economic and Statistics, 76, 12-21. 
Jiménez, J.L. and Betancor, 0., 2012. When trains go faster than planes: the strategic reaction of airlines in Spain, Transport Policy, 23, 34-41.

Krugman, P., and A., J., Venables, 1995. Globalization and the inequality of nations, The Quarterly Journal of Economics, 110, 4, 857-880.

Lago-Peñas, S., 2004. Local governments' asymmetric reactions to grants: looking for the reasons. Papeles de trabajo del Instituto de Estudios Fiscales, Serie Economía, 22

MEH, 2013. Estadísticas territoriales. Ministerio de Economía y Hacienda, http://www.minhap.gob.es/

Munnell, A. H., 1990. How does public infrastructure affect regional economic performance? Federal Reserve Bank of Boston, 69-112.

Pettersson-Lidborn, P., 2001. An empirical investigation on the strategic use of debt. The Journal of Political Economy 109 (3), 570-583.

Puga, D. 2002. European regional policy in light of recent location theories. Journal of Economic Geography, 2 (4), 373-406.

SACTRA, 1999. Transport and the economy: Full report. The standing advisory committee on trunk road assessment (SACTRA).

Solé-Ollé, A., 2006. The effects of party competition on budget outcomes: empirical evidence from local government in Spain. Public Choice 126 (1), 145-176.

Solé-Ollé, A., 2006b. Expenditure spillovers and fiscal interactions: Empirical evidence from local governments in Spain. Journal of Urban Economics, 59 (1), 3253.

Thompson, L. S., 1994. High Speed Rail in the United States - Why Isn't There More?, Japan Railway and Transport Review, 32-39.

Van den Berg, Leo, and Peter Pol. 1998. The European High-Speed Train-Network and Urban Development. Aldershot, UK: Ashgate. 
Vickerman, R. W. (ed.), 1991. Infrastructure and regional development, Pion, London.

Vickerman, R. W., 2002. Transport and economic development in Transport and Economic Development, Round Table 119, 139-177, OECD, Paris.

Voltes-Dorta, A., Jiménez, J.L., and Suárez-Alemán, A., forthcoming. An initial investigation into the impact of tourims on local budgets: a comparative analysis of Spanish municipalities, Tourism Management.

Zárate, A., and Vallés, J., 2012. Comportamiento tributario de los gobiernos locales españoles, XV Encuentro de economía aplicada, La Coruña 2012. 


\section{Annex I}

This annex provides a descriptive analysis of the evolution of HSR passengers in Spain for the 20 most important pairs of origins and destinations in terms of transported passengers.

Table AI.1. Evolution of HSR passengers in Spain between main corridors

\begin{tabular}{|c|c|c|c|c|c|}
\hline Corridor & 2008 & 2009 & 2010 & 2011 & \% Change 2011-2008 \\
\hline Madrid - Barcelona & $2,337,913$ & $2,651,598$ & $2,574,92$ & $2,515,681$ & $7.60 \%$ \\
\hline Madrid - Sevilla & $2,577,959$ & $2,386,736$ & $2,216,572$ & $2,140,942$ & $-16.95 \%$ \\
\hline Madrid - Valencia & 817,812 & 755,091 & 728,000 & $1,815,234$ & $121.96 \%$ \\
\hline Madrid - Málaga & $1,490,013$ & $1,499,879$ & $1,434,161$ & $1,440,953$ & $-3.29 \%$ \\
\hline Madrid-Zaragoza & $1,610,501$ & $1,361,161$ & $1,256,190$ & $1,174,158$ & $-27.09 \%$ \\
\hline Barcelona - Valencia & 835,447 & 879,607 & 883,989 & 839,310 & $0.46 \%$ \\
\hline Madrid - Córdoba & 984,430 & 872,034 & 852,652 & 801,684 & $-18.56 \%$ \\
\hline Madrid - Alacant & 821,178 & 763,176 & 706,000 & 707,675 & $-13.82 \%$ \\
\hline Barcelona - Zaragoza & 602,914 & 526,428 & 525,136 & 494,892 & $-17.92 \%$ \\
\hline Madrid - Valladolid & 806,767 & 550,973 & 458,234 & 436,604 & $-45.88 \%$ \\
\hline Madrid - Pamplona & 300,000 & 336,481 & 343,814 & 352,558 & $17.52 \%$ \\
\hline Madrid - Tarragona & 347,000 & 321,23 & 313,473 & 294,927 & $-15.01 \%$ \\
\hline$\underline{\text { Madrid - Murcia }}$ & 286,958 & 274,838 & 258,936 & 251,040 & $-12.52 \%$ \\
\hline$\underline{\text { Madrid - Lleida }}$ & 287,883 & 269,908 & & & \\
\hline$\underline{\text { Barcelona - Alacant }}$ & 251,632 & 249,651 & 241,618 & 243,806 & $-3.11 \%$ \\
\hline Madrid - León & 122,270 & 223,000 & 221,054 & 236,231 & $93.20 \%$ \\
\hline Barcelona-Castellón & 223,311 & 202,047 & 190,198 & 204,022 & $-8.64 \%$ \\
\hline Madrid-Cuenca & & 53,610 & & 144,000 & \\
\hline Madrid-Santander & 148,977 & 151,874 & 145,695 & 142,204 & $-4.55 \%$ \\
\hline Madrid - Donostia e Irún & 125,000 & 137,000 & 151,352 & 138,205 & $10.56 \%$ \\
\hline
\end{tabular}

Source: Statistics of the Ministry of Transport. Available on the website. 
By comparing the aggregate, we observe that there is a decrease in traffic between 2008 and 2011 . The percentage decrease is $4.03 \%$. In fact, there are only six routes whose traffic increased during this period. This is due mainly to the crisis (e.g. for the Madrid-Barcelona route, the decrease in traffic is around $22 \%$ for the same period).

Regarding the construction costs of any particular HSR route, we have a lack of data because they are not public and, sometimes, the information is even contradictory. Nevertheless, we have some examples of the important construction costs associated with this infrastructure (Table AI.2).

Table AI.2. Construction costs of HSR lines

\begin{tabular}{cc}
\hline Corridor & Construction costs per km. \\
\hline Madrid - Segovia - Valladolid & $21.72 \mathrm{M€/Km} \mathrm{(2006)}$ \\
\hline Córdoba - Málaga & $19.24 \mathrm{M} / \mathrm{Km}$ \\
\hline Madrid - Zaragoza - Barcelona - Frontera Francesa & $15.88 \mathrm{M} € / \mathrm{Km}$ \\
\hline Madrid - Levante & $15.07 \mathrm{M} € / \mathrm{Km}$ \\
\hline Madrid- Seville & $4.88 \mathrm{M} € / \mathrm{Km}(2001)$ \\
\hline
\end{tabular}




\section{Annex II}

We also enquire whether results on local revenues are caused by an increase in local taxes rates (using the yearly property tax, the most important at the local level in Spain) ${ }^{14}$ or by a better economic performance at the local level (see Hernández, 2012).

The results obtained in this table must be biased if the local government changed this tax rate after HSR entrance. For this reason, we repeat the estimations in equation [1] by using the yearly property tax as an endogenous variable. Table 7 analyses the effect of the entrance of HSR in this regard.

Table 7. DiD estimation of the yearly property tax on the entrance of HSR

\begin{tabular}{|c|c|c|c|c|c|}
\hline $\begin{array}{l}\text { Entrance of } \\
\text { HSR in... }\end{array}$ & Observations & HSR station & $\begin{array}{l}\text { HSR station } \\
+ \text { buffer } 5 \\
\text { kms }\end{array}$ & $\begin{array}{c}{[5-10} \\
\text { kilometers] }\end{array}$ & $\begin{array}{c}{[10-20} \\
\text { kilometers] }\end{array}$ \\
\hline 2003 & 26,573 & $0.01(0.59)$ & $-0.02(0.03)$ & $0.01(0.02)$ & $-0.02(0.01)^{* *}$ \\
\hline 2005 & 26,095 & $-0.01(0.05)$ & $-0.03(0.03)$ & $-0.02(0.02)$ & $-0.04(0.01)^{* * *}$ \\
\hline 2006 & 26,035 & $-0.01(0.03)$ & $-0.02(0.02)$ & $0.02(0.02)$ & $-0.02(0.01)$ \\
\hline 2007 & 26,623 & $0.01(0.04)$ & $-0.03(0.02)$ & $-0.02(0.02)$ & $-0.04(0.01)^{* * *}$ \\
\hline 2008 & 26,285 & $-0.01(0.04)$ & $-0.03(0.03)$ & $-0.01(0.02)$ & $-0.03(0.01)^{* *}$ \\
\hline
\end{tabular}

Note $1:{ }^{* *} 1 \%,{ }^{* *} 5 \%,{ }^{*} 10 \%$ significance test. Standard deviation in brackets.

Note 2: Identifying assumption is satisfied in bolded rows.

Although 'identifying assumption' is satisfied in years 2006 and 2007, all these estimations conclude that no changes in property tax have occurred since the entrance of HSR in the local governments affected by this development. Only in remote municipalities did we find a decrease in the tax rate of around 0.04 percentage points. These results are similar to those obtained in the descriptive analysis in Table 3 and, in fact, they induce lower local taxation in treatment cities than in the control group.

\footnotetext{
14 Delgado and Mayor (2011) state that the property tax, motor vehicle tax and building activities tax jointly represent
} $80 \%$ of tax revenue at the local level in Spain. In fact, property tax represents $49 \%$ of local tax revenues. 